\title{
The Match Between Job Description And Personality Of Batak Toba Prospective Pastors
}

\author{
Feddy Butarbutar, S.Psi, M.Psi \\ Department of Psychology \\ University of HKBP Nommensen Indonesia \\ e-mail : freddybutarbutar@uhn.ac.id
}

\begin{abstract}
The match between personality characteristics with job description will affect individual happiness when carrying out their duties. Likewise, pastors who have to carry out various tasks for which they are responsible. This study aims to analyze the suitability of the job description with the personality of prospective pastors in one of the tribal churches in Indonesia. The needs profile was revealed using Edward Personal Preference Schedule. In this tribal church organization the job description of the pastor was as follows: (a) serve as the main minister and church leader, (b) equip members to serve (c) Serves as overseers for organists and music leaders, Sunday school administrators, and various sections in organizations in the church (d) plan and conduct services, preach the word of God, serve the sacrament (e) serve as advisory members to all official groups in the congregation. The research respondents were 96 prospective pastors who came from the Batak Toba tribe.

The results of this study indicate that the need of aggression of respondents tends to be low and this supports the implementation of duties as a priest. The needs that are classified as moderate and supportive are the need of deference, need of order, need of interception, need of dominance and need of nurturance. While the needs that are less supportive in carrying out the job description of pastors are need of autonomy, meed of exhibition, need of abasement, need of affiliation and need of endurance all of which are relatively low.
\end{abstract}

Keywords: pastor, needs, personality.

\section{Introduction}

Becoming a pastor is a dream shared by some young people in North Sumatra. The strong desire of youth to become pastors can be seen in the theological school student selection which imposes a rigorous selection process so that many do not pass the selection process to become students at theological school. In fact, not all theology school students are able to complete their studies well. Based on information obtained from theological school management, there were found some students who felt uncomfortable in participating in various activities at theological high school. 
If while attending the learning process at theological school, there are some students who are less happy when they live it, what about those who have completed their studies, attended internships and applied to become pastors. Do they have the right personality characteristics to carry out various duties as pastors?

Polk (2007) explains that the duties of the pastor require certain characters that he must have so that he is able to carry out his duties well. The first of course has a good relationship with God through personal prayer and service that he does. Pastors are expected to have the ability to build relationships with others. He must be able to put themselves in the shoes of others, treat others in a good manner, as well as care and respect. Pastors must have empathy so that they can understand others personally including understanding how the struggle, success and sadness experienced by others. Relationships that are built both with internal and external parties will support the pastor in carrying out its functions. Pastors also have a duty to guide and direct the congregation. In this case there is an element of how to discipline to follow certain standards of behavior in accordance with the truth of the word. Pastors must be able to provide clear boundaries of what can and cannot be done, and then make corrections to violations that occur based on love. The pastor must be a person who is easily approached by others. The pastor is not a professional who is difficult to approach, instead he is a shepherd who has compassion. The pastor must be able to be a good listener, not only hear what is said, but also follow up by providing input or solutions.

Based on the church regulations (2002) where this research is carried out, the duties of the pastor are (1) to lead the congregation, plan and carry out services in accordance with the church's vocation duties, (2) lead the full-time ministry in accordance with their respective duties, (3) chairing congregational meetings, servant meetings, ordination meetings and leadership election meetings, (4) carrying out the decisions of the Great Synod, Synod Workers' Assembly Meetings, District Synods, Resort Meetings, Resort Assembly Meetings, Congregation Meetings and Ordinary Servant Meetings, (5) Oversee, guide and improving services in the area of stewardship and administration of the congregation, (6) receiving accountability reports for each council, (7) submitting service reports, statistics and congregation finances.

The personality is one aspect of research in the field of psychology that is widely investigated because it is indeed the broad impact of personality on many sides of life. Many definitions of personalities with each other have similarities as well as differences. However, from many theories, the author concludes several important things related to personality, namely personality is an active force in an individual. Personality regulates individual adjustment and determines how individuals respond to various stimuli from their environment. 
Research on personality associated with work is increasingly being done. Personality is a pattern of feelings, thoughts and behavior that is relatively stable. Each person has a unique personality that is different between individuals. Personality influences the tendency of individuals to behave in various situations (Bushoff \& Arnolds, 1995). Henry A. Murray (in Hall \& Lindzey, 1993) states that personality is a function that directs individuals. Personality integrates conflicts and obstacles faced by individuals, satisfying individual needs and devising plans to achieve goals in the future. Murray's theory emphasizes the need for something abstract but related to physiological processes in the brain. Murray states that the needs are: (1) the result of behavior, (2) the pattern of certain behavior, (3) attention and selective response to stimulus groups, (4) certain emotional expressions, (5) expressions of satisfaction when achieved or disappointment if not reached. According to Murray's theory (Murray \& Mc Adams, 2007), needs can be classified as follows: (1) need of dominance, (2) need of deference, (3) need of autonomy, (4) need of aggression, (5) need of abasement, (6) need of achievement, (7) need of sex, (8) need of sentience, (9) need of exhibition, (10) need of play, (11) need of affiliation, (12) need of rejection, (13) need of succorance, (14) need of nurturance, (15) need of infavoidance, (16) need of defendance, (17) need of countraction, (18) need of hermavoidance, (19) need of order and (20) need of understanding. One of the bestknown and earliest personality test kits is Edward's Personal Preference Schedule (EPPS). The EPPS explains about interesting concepts in the formation of personality test kits such as the concept of ipsative scores. In developing EPPS, Edwards selected 15 needs from Murray's list of needs, developing items by conducting content validations (Kaplan and Saccuzo, 2009). The needs compiled by Edwards are as follows: (1) Need of achievement which is the need to achieve achievement, (2) Need of deference which is the need to follow the rules, (3) Need of order which is the need to carry out a task regularly , (4) Need of exhibition which is the need to get attention, (5) Need of autonomy which is the need to take action independently, (6) Need of affiliation which is the need to establish relationships, (7) Need of intraception needs to understanding other people, (8) Need of succorence which is a need to get support from others, (9) Need of dominance which is a need to control others, (10) Need of abasement which is the need to feel guilty, (11) Need of nurturance which is a need to help others, (12) Need of change needs for change and new experiences, (13) Need of enduran ce the need to complete tasks, (14) Need of heterosexuality which is the need to establish relationships with the opposite sex, (15) Need of aggression which is the need to attack others.

\section{Significance of the study}

The results of this study provide insights that the compatibility between needs and job description is important so that pastors can carry out their roles happily. When pastors carry out their role comfortably, of course, supports the quality of their ministry. The results of this study can also be applied in the recruitment and selection process to get pastors with needs that match the job description so that good performance can be generated. Likewise in the development process, the results of research can be applied 
to determine training and development activities that are appropriate to the pastor's needs.

\section{Scope and Limitation of the study}

This study has limitations in terms of research samples. To increase the benefits of this study, it is recommended that the number of samples be extended not only to prospective pastors, but also to junior pastors and senior pastors so that they obtain data that illustrates pastors as a whole including differences in needs for pastors based on years of service.

\section{Setting of the study}

This research was conducted in the largest tribal church located in North Sumatra in 2019. This church was established in 1861 and was officially recognized by the Indonesian government.

\section{RESEARCH DESIGN AND METHODOLOGY}

This study aims to determine the needs of prospective pastors. To determine this need, Edward's personal preference Schedule (EPPS) psychology test was used. The results of this test were included in the EPPS norm by categorizing into the categories of low, tend to be low, medium, tend to be high and high. Then the compatibility between the needs and the job description of the pastor was seen.

\section{Respondents of the study}

Respondents in this study were 96 prospective pastors of one church. All research respondents are theological scholars who have completed studies in theology and have undergone an internship process as a condition of obtaining a bachelor's degree.

\section{Sampling Procedure}

The sampling technique used in this study is total sampling. All prospective pastors who applied to the church were respondents in the study.

\section{Research Instrument}

The instrument used was Edward's Personal Preference Schedule which is a psychological test used to express needs. This test tool consists of 225 pairs of statements in which respondents must choose one of two statements in each statement pair. The subject was asked to choose the statement that best suits him.

\section{Data Gathering Procedure}

Data collection was carried out by giving EPPS to prospective pastors in one of the tribal churches in North Sumatra. Researchers explain how the process of filling the EPPS instrument. After the research respondents are finished filling, the researcher collects. Next, the researcher checks and incorporates EPPS norms to determine the categories of each requirement. 


\section{Statistical Analysis}

The statistical analysis used is to categorize the hypothetical mean based on the standard norms of the EPPS assay. Then the empirical mean is calculated. The results of the empirical mean are included in the low, tend to be low, medium, tend to be high and high categories.

\section{FINDINGS AND CONCLUSIONS}

In the process of analyzing data in this study, the categorization is based on the hypothetical mean. The categorization can be seen in table 1 below.

Table. 1. Categorization based on hypothetical mean

\begin{tabular}{|c|l|c|}
\hline No & \multicolumn{1}{|c|}{ Kategorisasi } & Skor \\
\hline 1 & Low & X 7 \\
\hline 2 & Tends to be low & $7 \leq$ X 12 \\
\hline 3 & Medium & $12 \leq$ X 16 \\
\hline 4 & Tends to be high & $16 \leq$ X 21 \\
\hline 5 & High & $21 \leq \mathrm{X}$ \\
\hline
\end{tabular}

a. Tending to be high means that those needs have the potential to be actualized in behavior

b. Medium means that sufficient individual needs have the potential to be actualized in behavior

c. Needs that tend to be low are defined as needs that are less likely to be actualized in behavior

d. Low is defined as a need that is less likely to be actualized in individual behavior.

Furthermore, it is compared between the hypothetical mean and the empirical mean. The result can be seen in the following Table 2:

Table 2. Profile of the needs of prospective pastors

\begin{tabular}{|c|c|c|}
\hline Need & Mean Empirik & Kategori \\
\hline Achievement & 9,6 & Tend to be low \\
\hline Deference & 13,6 & Medium \\
\hline Order & 12,4 & Medium \\
\hline Exhibition & 10,0 & Tend to be low \\
\hline Autonomy & 7,7 & Tend to be low \\
\hline Affiliation & 11,6 & Tend to be low \\
\hline Intraception & 12,3 & Medium \\
\hline Succorance & 9,5 & Tend to be low \\
\hline Dominance & 12,2 & Medium \\
\hline Abasement & 11,1 & Tend to be low \\
\hline
\end{tabular}




\begin{tabular}{|c|c|c|}
\hline Nurturance & 12,1 & Medium \\
\hline Change & 11,5 & Tend to be low \\
\hline Endurance & 11,9 & Tend to be low \\
\hline Heterosexual & 8,2 & Tend to be low \\
\hline Aggression & 8,0 & Tend to be low \\
\hline
\end{tabular}

The needs profile can be seen in the bar diagram below.

Diagram 1. Need profiles in the form of bar charts

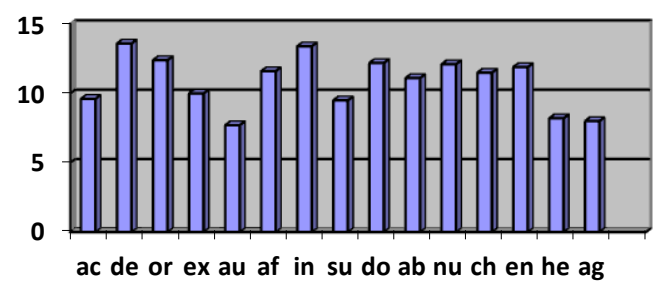

This study uses the Edward Personal Preference Schedule (EPPS) test that contains 225 statements to reveal the needs of 96 research respondents. Based on research data processing, it is known that most of the needs of research respondents are in the category of needs that tend to be low and needs that are classified as moderate. Not found any needs that are classified as low, needs that tend to be high and and needs that are classified as high.

Individual needs will direct their behavior toward actions that will satisfy those needs. High needs are more likely to be actualized in behavior than low needs. Each individual has a unique spread of needs, each other will be different. If it is related to the job description, then individual needs should be in accordance with the demands of behavior in accordance with the job description they have. Work as a pastor has a specific job description that requires a series of appropriate behavior so that the work can be done well. Behavior is based on the needs that stand out in the individual. Marzuki (2010) many studies indicate that differences in psychological well-being at work are related to differences in individual personalities.

If someone does not have a strong need that encourages productive behavior, then someone may not function optimally, for example work that requires to appear in public with great intensity will be difficult for individuals with low need of exhibition. There is a possibility that he will be difficult to adapt and less happy in carrying out the task. According to Murray (in Hall \& Lindzey, 1993) an satisfied need will bring happiness and vice versa an insatiable need will bring disappointment. Need of autonomy with an empirical mean of 7.7 shows that the need is the lowest in the research respondents. Need of autonomy is the need to act independently without having to be instructed by superiors or other people. This need becomes something that is less likely to be displayed in behavior. Thus there is a tendency that prospective pastors in this study still do not dare to make decisions independently so that they need support from others around them, especially those who have the 
authority in making decisions. There is a possibility that the low need for autonomy is caused by educational patterns that emphasize the importance of following what is set and lack of opportunities to make decisions independently. Prospective pastors are graduates of theological schools who have apprenticed to churches with the guidance of more senior pastors. As prospective pastors who was apprenticed, there was less opportunity to take action independently related to carrying out daily tasks. But actually, this need of autonomy needs to be increased so that prospective pastors are able to carry out their functions in the management of various activities in the church. Need of aggression is the need to attack others or criticize others. The empirical mean of research respondents is 8.0 which means it is in the category that tends to be low. In other words, it is unlikely that research respondents attack others directly in various social interactions. This is a positive thing related to the work of pastors who are required to control themselves from forms of anger and other forms of aggression. The empirical mean of the need of succorance of 9.5 is relatively low. Need of succorance describes a person's need to get the attention and support of others, it can be concluded that these needs tend to be low. In the context of service, it is better to give than to receive, the need of succorance that tends to be low is a supportive condition in service.

Need of achievement tends to be low with an empirical mean of 9.6, meaning that research respondents are not too compelled to achieve high achievement in work. This is less supportive, because the need of achievement is also needed to encourage individuals to do their best work. While the need of affiliation also tends to be low, as a minister in the church it is expected that pastors can interact harmoniously. Thus this need becomes less supportive in carrying out the task.

Need of endurance is in the category that tends to be low, meaning there is a tendency for pastor candidates to be less resilient in facing various obstacles. While in the ministry as a priest, it is not uncommon to encounter various obstacles so the ability to overcome difficulties is needed.

Need of nurturance that is classified as moderate, this need is quite supportive in service. This means that there is encouragement to support and help others. As a minister, a pastor is expected to be a person who is able to give advice to the congregation. Even in the context of service the need of nurturance should be high, not just a medium category. Because serving is central to the work of a pastor.

The needs that are classified as moderate are the need of deference, need of order, need of intraception, need of dominance and need of nurturance. Need of deference is a need with the highest empirical mean of 13.6. This means that this need has enough potential to be actualized in the form of behavior. The respondents of this study simply had the need to follow the rules in force in the institution where he served. Need of order has an empirical mean of 12.4 , it can be seen that there is potential to carry out tasks regularly following prevailing work patterns. Both of these needs support in terms of carrying out administrative tasks, to carry out tasks properly organized. 
Need of intraception and need of nurturance each have an empirical mean of 12.3 and 12.1 in the medium category so that the respondents in this study were mostly quite motivated to understand the feelings of others and help or serve others. With both needs that are potentially actualized, they will support in serving those who really need a feeling sensitivity and desire to serve and help strong. As workers engaged in services even these needs should be classified as high.

Meanwhile, the need of dominance is in the medium category with an empirical mean of 12.1 meaning that this need has the potential to be actualized in behavior. This need is related to the drive to control others in taking an action. Prospective pastors who will mostly be involved in the management of a church should indeed have enough encouragement to direct others while still being accompanied by the need to serve and the need to empathize with others.

Based on the description above, it can be concluded that there is a need to support the implementation of the job description as a prosperctive pastor who is a low need of aggression. The needs that are classified as moderate and supportive are the need of deference, need of order, need of intraception, need of dominance and need of nurturance. While the needs that are less supportive in carrying out the job description of pastors are need of autonomy, need of exhibition, need of abasement, need of affiliation and need of endurance all of which are relatively low.

\section{RECOMMENDATIONS}

First, church as user of prospective pastors pay attention to the needs of each individual in the selection process. With the needs in accordance with the job description, it is predicted that a pastor will feel happier in carrying out his duties. Because according to the theory of need, happiness will be obtained if the needs are actualized in behavior. It would be nice if a pastor in the tribal church where this research is conducted is pastors who do have needs that are in accordance with job descriptions such as high need of nurturance.

Second, the church can use the results of this research in the training and development process where needs that are not in accordance with the job description can be given reinforcement, such as low need of affiliation while pastors have to build relationships so they are given reinforcement so that the pastor can actually be more comfortable in interacting.

Third, for theological schools where prospective pastors are formed through a series of education. Can pay attention to the needs of each student so that they can provide support to strengthen the needs that are still less supportive and strengthen the needs that are really needed in services such as the need of nurturance and the need of affiliation. 


\section{REFERENCES}

Bushoff, C \& Arnolds, C. (1995). Some Antecendents of Employee Commitment and Their Influence on Job Performance. South African Journal of Business Management Volume 26

Celik, A., Kilinc, S and Ulukapi, H. (2016). A Study on Basic Needs in Oeganizations: The Relationship Between Physiological-Social and Motivational Needs of Forces Personnel. Advances in economics and Business Management. Volume 3: Krishi Sankriti Pulication.

Gasper, D. (2007). Conceptualizing Human Needs and wellbeing. www.researchgate/researchgate.net/publication

Hall, C.S \& Lindzey, G. (1993) Teori-teori Psikodinamik. Yogyakarta Indonesia

Ilies, R. Dimotakis, N. \& De Pater, I.E. (2010). Psychological and Physiological reaction to high workload: Implicathion for well being. Personnel Psychology, 63.

Kaplan, R.M., \& Saccuzo, D.P. (2009) Psychological Testing: Principles, Application and Issues. USA: Wadsworth Cengage Learning.

Marzuki, N.A. (2010). The Impact of Personality on Employee Well Being. European Scientific Journal. Vol 9. https://pdfs.semanticscholar.org/a574/

Murray, H.A \& McAdams, D.P. 2007. Explorations in Personality. $70^{\text {th }}$ Anniversary Edition. USA: Oxford Press

Polk, S.N. (2007) The Twenty-First Century Pastor: His Calling, Character and Competencies. Liberty Theological Seminary 